\title{
O jornalista Costa Rego e o tempo revolucionário (1930) ${ }^{1}$
}

The journalist Costa Rego and the 1930 revolutionary time

Noé Freire Sandes ${ }^{*}$

Resumo

Minha sugestão:

Costa Rego foi um dos mais respeitados jornalistas do seu tempo, atuando no principal jornal do país, o Correio da Manhã. Neste artigo acompanho detidamente a análise do jornalista sobre a atuação da Constituinte de 1934 e seus desdobramentos. O jornalista contestou, com obstinação, a anulação de sua própria experiência como homem público, ao defender o projeto liberal como opção política para o Brasil, após a revolução de 1930.

Palavras-chave: Correio da Manhã; Revolução de 1930; Costa Rego.

\begin{abstract}
Costa Rego was one of the most respected journalists of his time. He wrote for the main newspaper of the country, the Correio da Manhã. In this article I carefully observe Rego's analysis of the actuation of the '1934 Constituent' and its implications. The richness of his point of view comes out of the accurate look he provides of that revolutionary moment. This journalist contested, with obstinacy, the destruction of his own experience as a public personality, defending the liberal project as a political option for Brazil, after the Revolution of 1930.

Keywords: Correio da Manhã; The Revolution of 1930; Costa Rego.
\end{abstract}

${ }^{\star}$ Depto. de História - Universidade Federal de Goiás (UFG) - Pesquisador CNPq, Campus Samambaia II, CP 131 74000-000 Goiânia - GO - Brasil. noe@fchf.ufg.br. 
Vocês deitaram o Brasil de pernas para o ar. Não tenho entusiasmo pelo que fizeram. Sinto-me, cada vez mais, por formação, tendências e, quem sabe? herança dos meus, um homem da direita, que não acredita em certos deuses da democracia, um dos quais, aquele que você invocou, a Opinião, eu bem sei como se fabrica. Mas isso não me impede de desejar que homens como você e alguns outros, estimáveis - muito poucos - que vejo com a responsabilidade de recolher a louça quebrada, sejam felizes em sua missão, se dela pode resultar o bem do Brasil. ${ }^{2}$

Em 21 de abril de 1931, Costa Rego escrevia, em tom de desabafo, para o ministro da Justiça Afrânio de Melo Franco que, à época, o aconselhava a não retornar ao Brasil. O jornalista desconfiava da opinião formada sobre o processo revolucionário em curso, pois no tumulto dos acontecimentos, percebia-se, no entrechoque entre militares e civis que dirigiam o movimento, a ausência de rumo. Não havia concordância sobre o futuro da Revolução entre as lideranças que conduziram o processo e os que arremataram o seu desfecho, com a deposição do presidente Washington Luís.

A Revolução ainda não contava com uma base mínima de consenso para redefinir as urgentes medidas de reordenação da ordem política; portanto, restava, como opção, apostar no restrito grupo de conspiradores de primeira hora. Diante do clima de desconfiança e dos boatos de golpe, Vargas resolveu deslocar tropas para ocupar militarmente São Paulo. Iniciou-se abertamente o dissídio, quando os paulistas se perceberam alijados da governança de sua própria terra. A Revolução fabricava, assim, os seus inimigos. As negociações com o Partido Democrático não prosperaram: a participação de militares, como João Alberto e Miguel Costa, no governo de São Paulo indicava uma intromissão inaceitável para os ciosos defensores da pátria paulista. Não tardou para que o ambiente de sedição ganhasse força e, em julho de 1932, assumisse uma forma revolucionária. Sendo assim, as primeiras reflexões sobre o movimento de 1930 carregam as marcas desse conflito.

Barbosa Lima Sobrinho, em 1933, definiu as causas da Revolução como resultado do embate regionalista. Segundo o jornalista, o liberalismo era mera aparência, "açúcar indicado para esses momentos", pois o traço definidor da crise política de 1930 foi o desequilíbrio entre o poder dos Estados Federados. As forças de dispersão se mantiveram presentes após a revolução de outubro, e Getúlio Vargas, atento às possibilidades de recomposição do poder regional, decidiu conter a grande força política representada por São Paulo. ${ }^{3}$ 
Costa Rego, em 1931, antecipava a avaliação de que a Revolução já abandonara os compromissos políticos firmados na Aliança Liberal. Do exílio, na França, o experiente jornalista contava os dias para voltar à sua terra e ao jornal em que labutava nas letras e na política, desde 1906. ${ }^{4}$ Sua experiência, como político e jornalista, indicava a proximidade de um novo embate: tratavase de entender e interpretar o tempo da revolução.

Na carta endereçada a Afrânio de Melo Franco, Costa Rego expressa sua incerteza quanto ao futuro que se anunciava, em 1930, para o Brasil. Em especial, a expressão "recolher a louça quebrada" guarda um significado especial. Recolher a louça para quê? Seria possível reconstituir os pequeninos fragmentos da frágil porcelana, quem sabe inglesa, como se fizera em tantas crises enfrentadas na Primeira República? O Correio da Manhã contava com uma força política nada desprezível, dada a sua tiragem de 140 mil exemplares diários, e acompanhava, com certa distância, o movimento da Aliança Liberal, desejoso de manter-se aberto aos possíveis vencedores.

O exílio de Costa Rego foi motivado, principalmente, pela sua liderança como ex-governador e senador pelo estado de Alagoas. Mas no ano de 1931, retornou às páginas do Correio. Seus escritos, sempre publicados no canto esquerdo da página dois, dedicada principalmente aos artigos de opinião, aproximavam-se da crônica, pois rememoravam fatos corriqueiros do passado, como pistas que poderiam conduzi-lo ao centro do debate político. No lado oposto, encontrava-se também uma coluna dedicada aos acontecimentos da Constituinte, registrando as decisões e as polêmicas ocorridas no seio da Assembléia. Desse modo, o leitor do Correio da Manhã tinha, portanto, acesso a formas distintas de apreciação dos acontecimentos. O estilo interpretativo de Costa Rego reforçava a credibilidade do articulista, porém, exigia certo afastamento do tom de 'conversa fiada' característico da crônica, visto que sua pretensão era convencer o leitor da veracidade de seus argumentos, resistindo, assim, ao devaneio sem compromisso que, segundo Candido, ${ }^{5}$ é a marca daquele gênero literário.

Nesse impasse, a escrita do 'quase-cronista' situava-se em terreno de difícil definição, já que a análise do evento político exigia outro olhar. Sob a condição de derrotado, de 'decaído', legitimamente armado pela experiência do passado, o jornalista buscava reinterpretar os acontecimentos do presente, especialmente o debate na Constituinte, estando preso, entretanto, à armadura institucional do Correio da Manhã. Ainda assim, encontrou estilo próprio. A política, tanto quanto possível, foi analisada ao rés-do-chão, onde jazia o móvel de toda disputa: o poder. 
Os jornais oposicionistas festejaram a vitória da Revolução de 1930, saudando a desejada renovação política anunciada nas rebeliões militares da década de 1920. O otimismo foi passageiro: a turbulência e o sectarismo dominaram o ambiente político, atingindo a imprensa. O jornal $A$ noite somente se livrou dos incendiários amotinados graças à pronta ação dos bombeiros. O jornalista Medeiros de Albuquerque descreve, em detalhes, a fúria popular contra O País, em 24 de outubro de 1930:

Chegados à janela, vimos, lá de longe, a imensa coluna de fumo, que se elevava do Edifício d'O país, incendiado. A avenida Rio Branco, na parte pelo menos em que nos achávamos, estava meio deserta. Passavam, entretanto, de tempos a tempos, grupos que aclamavam a revolução. Em um automóvel um desses grupos levava o retrato do general Mena Barreto. Alguém trouxera para a rua uma bobina de papel, tirada d'O País e ia desenrolando. Era um efeito curioso o desse tapete de papel, que vinha de tão longe, pondo um caminho branco no asfalto negro da rua. ${ }^{6}$

O contraste do branco do papel com o negror do asfalto anunciava novos tempos para jornais e jornalistas. O Correio da Manhã retirou o apoio ao governo quando percebeu a impossibilidade de qualquer freio aos seus ímpetos de controle sobre a opinião pública. A censura foi o instrumento básico de contenção da imprensa. Entretanto, sua atuação foi incapaz de silenciar completamente as vozes oposicionistas, desencadeando, assim, a depredação, em fevereiro de 1932, do Diário Carioca por um grupo de tenentes. A frágil reação governista diante da violência cometida por grupamentos militares abriu a primeira crise no governo provisório, o que resultou no rompimento de Vargas com antigos aliados do Rio Grande do Sul. Demitiram-se do governo Maurício Cardoso, ministro da Justiça, Batista Luzardo, chefe da polícia do Distrito Federal, e João Neves da Fontoura.

Costa Rego assumiu o papel de porta-voz de um tempo que os revolucionários queriam a todo custo apagar, embora dele ainda fossem prisioneiros. A falta de rumo da Revolução, tantas vezes denunciada pelo articulista, se devia à sobrevivência dos vícios do passado que perduraram para além dos marcos tradicionais da história política. A experiência da Primeira República não se decompôs em 1930. Ao contrário, havia uma clara possibilidade de esse passado resistir e indicar os rumos do presente, desde que fosse convocada a Constituinte. É nessa direção que o Correio da Manhã participa da campanha pró-Constituinte. Assim, o jornalista Costa Rego, em maio de 1931, ini- 
cia sua missão: resistir ao desejo de anulação do passado como pretendiam os reformadores do mundo.

Os reformadores do mundo sempre existiram. Quem o reformou pela primeira vez foi o próprio Deus. Note-se que Deus, já naquela época, não admitia a perfeição; e o mundo era, entretanto, obra sua. Os tolos e vaidosos é que se julgam autores de obras imperecíveis e perfeitas. Reformou Deus o mundo com o dilúvio universal, método sumário, ainda hoje de uso corrente. Mas o dilúvio não foi um ato de destruição; foi um ato de recomposição. Sua história está no Gênesis. Abramo-lo. ${ }^{7}$

O jornalista descreve a aventura do dilúvio e a confiança divina na tarefa redentora do homem velho que, graças à sua experiência, pôde salvar o mundo reunindo as distintas formas de vida, enfim o novo supõe sempre um pouco do velho. Costa Rego, sobrevivente do dilúvio revolucionário, era quem melhor traduzia os interesses do Correio da Manhã diante da nova moldura legal que a Constituinte elaborava. Para tanto, oferecia ao leitor a partilha da sua experiência, sugerindo um volver de olhos para o passado como forma de entender o presente. Dizia o que "via e ouvia" e, na forma de lição, iluminava cenários obscuros com sua prosa fácil, atingindo, com agudeza, o seu público.

O ex-governador de Alagoas, que mal voltara do exílio, foi incansável no exercício da comparação: apurou seus olhos e ouvidos para que sua escrita denunciasse o presente pela sua semelhança com o passado. Segundo ele, o Código Eleitoral, por exemplo, ensejou a formação de partidos, entretanto, "não impediu e até favoreceu, o aparecimento, de norte a sul, dos partidos dos governos locais, entretidos, alimentados e amparados pela ação do governo, tal como sempre se sustentou que eles existiam outrora".

Costa Rego afirmava, "em nome da verdade", que a insurreição militar derrubou apenas um governo, mas não o regime, pois a deturpação do espírito constitucional promovida pelos homens do passado se assemelhava ao que fizeram os revolucionários de 1930. Sob essa perspectiva, o que se apresenta como novidade esmaece perante a história. A lembrança é o repositório dos fatos que, se encadeados, falam por si, basta "ver e ouvir". "Dizer", entretanto, exige lançar o "visto e o ouvido" na arena política. Como um dos principais jornalistas do Correio da Manhã, Costa Rego cumpria distintas funções, "ouvia e via" como convém a esse arguto observador e, sobretudo, "dizia", incitando o seu leitor à reflexão crítica dos acontecimentos. 
Munido de extremo realismo político, Costa Rego se dispôs a pensar a "fisionomia" da Constituinte. Para o governo, o negócio constitucional poderia conduzir a dois resultados positivos e simultâneos: permitiria cumprir sua promessa, retirando de cena os apelos para a constitucionalização, e investiria o ditador de certa legitimidade. O perfil governista da Assembléia já se podia adivinhar, entretanto, e a capacidade da minoria de transformá-la em "instrumento", em um poder, constituiu uma hipótese sempre sugerida pelo Correio da Manhã.

O presente, para os revolucionários, era o mirante donde se poderia enxergar o passado em perspectiva evolutiva, pois a Revolução poria fim aos vícios do Antigo Regime. Essa percepção deveria ser interiorizada por todos para que a obra revolucionária edificasse o novo tempo. Em direção contrária, Costa Rego insistia em revelar o sentido primeiro do movimento que depôs o presidente Washington Luís: a Constituinte que, portanto, pôs fim ao drama de outubro de 1930. O centro da discórdia se restringiu, segundo Costa Rego, à preterição do presidente do estado de Minas, Antônio Carlos, nas combinações para a escolha do candidato à presidência da República. Eis a trama: o jornalista limitava sua interpretação ao conhecimento direto das ações dos atores políticos e de seus interesses imediatos, contrapondo-se, assim, à estratégia retórica que transformava a Revolução em um movimento abstrato, uma potencialidade natural que se desenvolveria a despeito da vontade dos homens.

A convocação da Constituinte fez-se mediante o compromisso de anulação do passado, e sua função restringia-se à elaboração da Constituição. Qualquer iniciativa que fugisse à finalidade constitucional deveria ser considerada estranha aos deveres da Assembléia. A suposta regra que visava eliminar o confronto político na Constituinte se contrapunha, no entanto, ao desejo de reparação de direitos pretendida pelas oposições ao reivindicarem, por exemplo, a anistia. O governo insistia em negar a validade de tal proposição revelando a sua ambigüidade ao incluir a eleição presidencial como missão da Constituinte. Tal perspectiva abriu uma fissura nos muros que protegiam os artífices do labor constitucional das questões candentes que mobilizavam a sociedade.

A fixação das novas regras para a eleição presidencial colocou em risco a cômoda posição dos constituintes, mas a maioria governista, escondida sob as vestes do formalismo jurídico, fez-se de cega e, ao evitar o debate político, sujeitou-se, freqüentemente, às vontades do governo discricionário, apesar dos protestos da minoria que se movimentava no restrito espaço controlado, 
habilmente, pelo maestro da casa, Antônio Carlos Ribeiro de Andrada. Ainda que as vozes oposicionistas se avolumassem, desejosas de expressão, estas eram sufocadas pelas táticas governistas que controlavam, por exemplo, a longa fila de inscrições para pronunciamento em Plenário.

$\mathrm{Na}$ oposição, havia grande expectativa em relação à postura da bancada paulista. A memória de 1932 exigia o firme posicionamento dos representantes de São Paulo que, apesar da derrota, contavam com um trunfo: a estratégia constitucional foi imposta ao tempo impreciso do governo revolucionário. Em $1^{\circ}$ de dezembro de 1933, Costa Rego fez ácidas críticas ao inesperado silêncio daquela bancada que demonstrou sua incapacidade de se situar no jogo político, diferentemente do que se esperava:

a brilhante bancada paulista abominava a política. O que ela queria, isto sim era uma Constituição. Nada, pois de assuntos à margem, embora pertinentes ao objeto da convocação da Assembléia. Uma boa constituiçãozinha, seguida de uma aprovaçãozinha dos atos do governo provisório, encerrada uma eleiçãozinha do Sr. Getúlio Vargas, tudo isso bem anotado, bem catalogado, bem fichado, bem sistematizado pela secretaria técnica do conselho da bancada. ${ }^{9}$

Costa Rego explicita o compromisso do grupo paulista com Vargas. O uso irônico dos diminutivos denuncia a aparente infantilidade da bancada que assumiu uma postura meramente técnica, em detrimento da discussão de problemas de natureza política:

Aqui chegando, a bancada logo se beneficiou da segunda de suas famas: o silêncio. Em uma fase como esta, quando todo homem público tem sempre uma declaração a fazer à imprensa, e quando o ilustre general Góis Monteiro, contrariando o conceito de Thiers sobre a mudez dos exércitos, é o campeão reconhecido e indiscutível dos colóquios com jornalistas, o silêncio daquela bancada era o índice de grandes cogitações. (ibidem, p.2)

O silêncio dos paulistas deixava de ser um enigma para se apresentar como o resultado de um negócio. $\mathrm{O}$ jogo de sedução do governo sobre os grupos oposicionistas é percebido de distintas formas, mas quando se trata da defesa da Federação, o debate torna-se acirrado. O representante do Rio Grande do Sul, João Simplício Alves de Carvalho, apontava para dezesseis pontos, em suas palavras, dezesseis 'facadas' do anteprojeto constitucional que enfraquecia a forma federativa de governo, destacando a proibição do uso de sím- 
bolos e hinos estaduais, a posse, pela União, de quedas d'água, rios e lagos navegáveis, bem como a posse dos serviços de viação férrea. Costa Rego afirma que o anteprojeto propõe um regime centralista de províncias escravas, retornando, mais uma vez, ao passado: "E pensar que a Revolução se fez em torno do símbolo da 'pequena e heróica Paraíba', a defender, 'até ao martírio', na frase do Sr. Antônio Carlos, sua autonomia vilipendiada”. ${ }^{10}$

Pensar a Revolução. Essa foi uma das mais importantes estratégias do colunista do Correio da Manhã para discutir o presente revolucionário. Tratava-se do combate rotineiro às mazelas do governo. A disputa entre os gaúchos Vargas, Oswaldo Aranha e Flores da Cunha inspirou um hilariante texto comparando as autoridades a instrumentistas, cuja 'afinação' dependia do controle político do Rio Grande do Sul. Vargas, comparado ao famoso pianista polonês Paderewski, era assim descrito: “Tem uma noção da amizade completamente despida de preconceitos. Um amigo é o que vale, até quando vale. Não é o Sr. Getúlio Vargas um homem: é um complexo". ${ }^{11}$

A atenção dedicada a Vargas ensejou artigo que ganhou notoriedade: "A pesca do Pirarucu". A enorme capacidade de convencimento e de atração exercida pelo presidente do governo provisório foi o mote para a comparação com a pesca do famoso peixe amazônico. Costa Rego descreve, com detalhes, distintas etapas necessárias para vencer o animal que só cede pela exaustão, depois do contínuo esforço para resistir ao movimento incessante - recolher e relançar - da linha. O peixe é conduzido entre a liberdade ilusória e o aprisionamento. Artifício idêntico o colunista enxergava nas estratégias políticas do presidente.

Ora, não é senão uma pesca de pirarucu o que o Sr. Getúlio Vargas faz, no desdobramento das crises da Revolução. Os homens que ele quer submeter, anular ou proscrever são primeiramente arpoados. Correm. Ao fim da linha, o Ditador suavemente os chama, resistindo, eles voltam, presos ao arpão. O Sr. Getúlio Vargas larga-os mais uma vez, e só os larga para que voltem, até que, extenuados, lhe possam aplicar o macete.

Quem quiser melhores informações sobre o assunto pode dirigir-se aos Srs. Borges de Medeiros, João Neves da Fontoura, Mauricio Cardoso, Lindolfo Collor, Baptista Lusardo, Barros Cassal, Francisco Campos, Adolfo Bergamini, Leite de Castro, Dulcidio Cardoso, José Maria Whitaker, Laudo de Camargo, Waldomiro Lima, João Alberto e outros pirarucus de antigas pescarias. Os da pescaria de agora falarão depois... ${ }^{12}$ 
O motivo da Revolução é descrito como cupidez, o refrão é repetido exaustivamente. Há, portanto, vícios e não virtudes. A continuidade da antiga ordem é denunciada no prolongamento do governo provisório. Não há razão para entregar o poder a outras forças políticas e nem mesmo a outros homens. Vargas negocia a sua permanência com antigos inimigos e estes cedem. Dessa forma, a justificativa para tal atitude poderia ser assim resumida: São Paulo preferiu negociar, pois as facções oposicionistas não dispunham de força suficiente para enfrentar o governo. Nessa avaliação, evidencia-se a estratégia conformista adotada pela bancada paulista. Mas o Correio da Manhã seguia pressionando a Assembléia Constituinte e, a despeito da censura, enfrentava o governo constituído.

O debate constitucional ganhava as ruas por meio dos jornais. Não é fácil mensurar a influência da coluna de Costa Rego entre os leitores cariocas, mas percebe-se, pelas cartas publicadas e pelo pronunciamento dos próprios políticos, que a imprensa, e em especial o Correio da Manhã, não apenas noticiava, mas também influía no encaminhamento do debate na Assembléia. Certas manifestações aludiam, claramente, às polêmicas provocadas pelo articulista. Cite-se, como exemplo, o fato de Alcântara Machado afirmar "que a bancada paulista não reconhece em ninguém, de fora de São Paulo, o direito de traçar-lhe os rumos na Constituinte", conforme registra o próprio jornalista no artigo "Não gostei", publicado em 11 de março de 1934. O discurso do líder paulista ensejou réplica de Costa Rego questionando duramente a omissão daquela bancada no combate às pretensões do ditador em eleger-se presidente constitucional. A proposta de supressão da inelegibilidade do chefe do governo provisório, para a primeira eleição regida pelas normas constitucionais, asseguraria a Vargas a possibilidade de acesso ao cargo. Em contrapartida, reinava na bancada paulista um clima de negociação mediado pelo interventor, Armando de Salles Oliveira.

A proximidade do pleito eleitoral acirrou as tensões: a candidatura de José Américo, apoiada pelo Correio da Manhã, e a de Góis Monteiro, sugerida pelo Clube 3 de Outubro, agitaram o ambiente político e intensificaram a indefinição do processo eleitoral, permitindo que as duas candidaturas ganhassem apoios, ainda que restritos. Os boatos de golpes chegavam, dia a dia, aos ouvidos de Vargas. A eleição, motivo de grande preocupação para o presidente, foi fartamente registrada em seu diário, com ênfase na desconfiança sobre a atuação dúbia de Góis Monteiro, freqüentemente citada nos rumores golpistas. Aos poucos, o apoio à candidatura do militar foi tomando a forma de um campo minado, conforme aviso de João Alberto, quando os Melo Franco 
insistiram em interpelar o general: “- Ora não amole. O Getúlio sabe de tudo. Não façam besteira. Vai prender vocês se insistirem. O Góis não se mete em revolução nenhuma ... Olha aqui, Afonso, você acha que se isso pudesse ter êxito eu ficava de fora?". ${ }^{13}$

Em maio de 1934, Costa Rego retoma o debate sobre a anistia, insistindo em qualificá-la como ato de insinceridade, pois apenas reeditava medidas já tomadas pelo governo discricionário. A recuperação dos direitos políticos por inúmeros cidadãos; a isenção das responsabilidades dos participantes do movimento de 1932 e a insubsistência das decisões do Tribunal Especial, segundo o jornalista, nada apresentavam de novo: a sua reedição apenas atendia aos interesses do ditador. A anistia deveria contemplar ainda os funcionários ilegalmente demitidos, mas o Decreto presidencial regulamentando o tema padecia de falta de clareza. Com base nesse diagnóstico, Costa Rego inverte a situação:

o que o decreto faz é conceder anistia ao Sr. Getúlio Vargas, pois, ao passo que lhe assegura o esquecimento de tudo quanto praticou, aos funcionários acena com uma vaga promessa de uma revisão oportuna de atos (oportuna sempre que morrer um elefante do circo Sarrasani), com exame de cada caso, para a conquista de um lugar equivalente, quando houver vaga.

Vamos, portanto, à maneira dos brindes de sobremesa, erguer nossas taças em honra do eminente Sr. Getúlio Vargas, o verdadeiro, o único anistiado. ${ }^{14}$

O esquecimento, ponto fundamental do processo de anistia, só pôde beneficiar o próprio presidente Vargas, então liberto de qualquer julgamento dos atos cometidos no passado revolucionário. Não se podia confiar, portanto, na comoção do ministro da Justiça, Antunes Maciel, notada no ato da assinatura do Decreto: "Não devemos, pois admitir que eles chorem hoje sobre as violências que foram os primeiros a praticar. Para essas violências não haverá jamais anistia”. ${ }^{15}$ Costa Rego salientava que, em vez de esquecimento e pacificação, a anistia sinalizou, tão-somente, a vitória do governo provisório que posava de abnegado. A conciliação somente foi proposta quando a base governista vislumbrou o atendimento de seus interesses. Restava apenas apagar o passado, retirando dos adversários as cicatrizes dos conflitos.

Ora, a paz seria impossível com a suspensão dos direitos políticos. O Sr. Borges de Medeiros, por exemplo, e os bravos companheiros que o acompanharam no Rio Grande do Sul obteriam, dentro em pouco, o prestígio do martírio. Ficariam necessariamente mais estimados. E isto aconteceria, por igual, em relação aos 
adversários do governo em todos os outros Estados. O restabelecimento dos direitos políticos tira-lhes um símbolo de valor indiscutível. ${ }^{16}$

Não satisfeito com a larga margem de manobra com a qual acreditava contar na Assembléia Constituinte, o governo impediu a imprensa de cobrir as sessões que definiriam as regras de elegibilidade para a Presidência da República, discutidas no início de junho. Em virtude do veto, somente após a concretização dos arranjos eleitorais é que pôde o Correio da Manhã se manifestar, em 8 de junho, sobre os acontecimentos. Costa Rego condenou, com veemência, a atuação da Constituinte, em artigo intitulado "Três provocações”. A primeira das aludidas provocações, segundo o jornalista, consistia na aceitação da elegibilidade do chefe do governo provisório. A segunda era mera decorrência da primeira, pois admitida a elegibilidade do presidente, tal medida se estenderia aos interventores, formando, enfim, uma elite governante constituída por 'usurpadores'. Finalmente, a terceira provocação referia-se ao debate sobre a prorrogação dos mandatos dos Constituintes.

O que o Correio da Manhã denunciava, de modo incansável, era a restrição do espaço político para os segmentos afastados da órbita do governo. $\mathrm{O}$ espírito de conquista permanecia e aos derrotados restava a difícil missão de reagir, projetando, como uma sombra, os erros do passado no presente indefinido. Os apelos do jornal reverberavam na Constituinte e tornavam público o complexo jogo político armado na Assembléia.

Na sessão de 17 de junho de 1934, o tema da prorrogação dos mandatos dos Constituintes foi associado à pretensão do governo de editar Decretosleis. A forte repercussão da campanha movida pela imprensa contra as medidas previstas teve saldo positivo, pois a referida prorrogação ateve-se ao prazo necessário à eleição da nova Câmara e o governo foi impedido de dispor do Decreto-lei na vigência plena da Constituição, tendo em vista o clima de desconfiança que, entre os Constituintes, cercou o chefe do governo provisório.

Essa nova conjuntura poderia chegar, até mesmo, a complicar o quadro sucessório, se fosse possível contar com a ação das lideranças políticas da oposição. O Correio da Manhã, de sua parte, buscava avivar os apetites de poder dos atores envolvidos nos conflitos que permearam o processo de consolidação da Revolução. Os sentimentos políticos afloram no momento em que Costa Rego põe-se a descrever os homens:

O Sr. Antônio Carlos é um homem nitidamente da Revolução. Inspirou-a, preparou-a, pagou-a. Sem a concepção diabólica de seu plano, sem os cuidados que 
ele lhe dedicou e sem o dinheiro que fez trafegar dos cofres públicos de Minas Gerais para o comando civil da conjura, em Porto Alegre, nada se haveria logrado realizar. Os "reacionários" — se por este nome ainda se indicam os vencidos — devem-lhe guardar um rancor todo especial. ${ }^{17}$

O presente anunciava novas tramas e conflitos. O passado era medicamento de uso tópico recomendado, especialmente, para os casos em que a defesa do argumento liberal necessitasse do espaço de experiências definido pela vivência dos homens da Primeira República. A estratégia narrativa do articulista conferia aos revolucionários uma identidade negativa derivada da partilha de um passado comum, que não fora superado. Entre o jornalista e o presidente da Assembléia Constituinte, Antônio Carlos, havia certa comunidade, pois ambos eram, afinal, antigos. O mesmo laço poderia estender-se a Getúlio Vargas e a tantos outros personagens de uma tradição política que teimava em persistir.

Costa Rego, como artífice da memória, entrelaça passado e presente em um nó cego, projetando o futuro na apertura de um tempo constituído pela sua experiência. Esse ajustamento decorre do fato de que o passado ainda se conserva como fonte de orientação e o futuro, fonte de ameaça, parece destituído de sentido, mostrando-se, muitas vezes, absurdo. O mais importante jornal do Rio de Janeiro insistia na defesa do ideário liberal formado, basicamente, pelo tripé liberdade de imprensa, federalismo e livre iniciativa. $\mathrm{O}$ jornalista sugeria prudência aos seus leitores, alertando-os sobre as semelhanças entre o passado e o presente. Tais semelhanças, entretanto, não descartavam mudanças que se anunciavam, muitas vezes, em direção inversa daquelas pretendidas ou esperadas: as propostas centralizadoras, envoltas sob a veste liberal, representavam quase um consenso no seio da Assembléia Constituinte.

As inovações trazidas pela política de massas e pelo poder da propaganda eram perceptíveis a Costa Rego. A Itália e a Alemanha eram vistas como vitrines dos modismos que encantavam os políticos brasileiros.

Há uma convicção generalizada, no meio de tantas outras, sobre a excelência da obra de Mussolini, em suas repercussões na vida italiana; e até mesmo de Hitler se pode acreditar que esteja reerguendo a Alemanha. O sistema da publicidade política é hoje, porém, tão entrosado na técnica das bulas farmacêuticas que se pode recomendar um regime com a mesma displicência que se põe na propaganda de um líquido para injeções. ${ }^{18}$ 
Atento à novidade dos regimes fortes, Costa Rego percebia que essa tendência se anunciava no governo revolucionário. O resultado das eleições era mais que previsível. A oposição se tornava tão invisível quanto o seu candidato, Borges de Medeiros. De certa forma, delineava-se mais uma disputa simbólica do que propriamente eleitoral. Os votos destinados ao Sr. Borges de Medeiros eram portadores de um sentido especial: colocavam frente a frente os dois próceres do mundo gaúcho, invertendo, apenas, as posições de mando. Enfim, restava ao grupo derrotado recompor suas ligações com os liberais, hipotecando apoio ao complexo equilíbrio que a Constituinte criou sob a direção de Antônio Carlos: "um sistema presidencial de freios e contrapesos, uma espécie de parlamentarismo sem a intervenção do Parlamento ou de presidencialismo sem a onipotência do Presidente". ${ }^{19}$

Costa Rego condena o sistema presidencialista na mesma edição em que o Correio da Manhã publica os principais tópicos do manifesto que Vargas distribuiu na Constituinte, fazendo um balanço dos resultados da revolução, quando de sua posse na Presidência da República. O presidente alertava para a necessária fixação de limites à liberdade de imprensa, dirigindo duras críticas aos excessos cometidos pelos jornais. Entretanto, registrava a promessa de continuidade do espírito revolucionário, sob forma constitucional.

Cumpre não confundir revolução com o episódio militar que a deflagra. Revolução é adaptação à realidade, compreensão segura dos fenômenos sociais, reconstrução do edifício do Estado sobre fundamentos sólidos. Os novos rumos abertos pela idéia revolucionária estão definitivamente traçados naquele momento. É impossível entravar-lhe a marcha progressiva determinada pela força de uma fatalidade histórica. Nem fórmulas caducas nem princípios inadaptáveis à nossa índole serão capazes de a deter. ${ }^{20}$

Vargas definia, com clareza, a temporalidade da Revolução como marcha, como fatalidade que se afasta do peso das ações individuais. Cabia à sociedade adaptar-se ao novo tempo. Ao perceber a ameaça velada do novo regime, o Correio da Manhã reagiu com nova e intensa campanha exigindo, agora, a alteração da lei que restringia duramente a liberdade de imprensa, estabelecendo penalidades para ações dos meios de comunicação, eventualmente consideradas abusivas.

Diante do conflito que se entrevia entre imprensa e Estado, restava ao jornalista reconhecer que os freios e contrapesos conferiam ao novo sistema político a marca da instabilidade, por isso era necessário resistir e insistir na 
crítica ao governo. A formação do novo ministério, por meio do critério geográfico, era indício claro do funcionamento das velhas e conhecidas regras da Primeira República e transformou-se em atrativo para que Costa Rego satirizasse, com grande dose de humor, a novidade criada pela Revolução: o jantar fúnebre. A invenção se materializou em Recife, quando Vargas, em visita ao Nordeste, foi surpreendido pela morte de Olegário Maciel. Na programação oficial, constava um jantar de gala em homenagem ao presidente. Apesar das circunstâncias adversas, o programa foi mantido. Entre silêncios e discursos, os convivas usufruíram o jantar.

Aproveitando-se da situação excêntrica, o jornalista político comenta um outro jantar oferecido aos ministros demissionários, quando da instituição da regra geográfica para a redefinição dos Ministérios. Tratava-se de homenagear os 'mortos' quando novos convidados se aprontavam para assumir seus cargos.

Quem entrou primeiramente foi o Sr. Antônio Carlos. Depositou os Srs. Odilon Braga e Gustavo Capanema. E saiu. Quem entrou depois foi o Sr. Armando Sales. Depositou os Srs. Macedo Soares (J. C.) e Vicente Ráo. Quem entrou imediatamente foi o Sr. Lima Cavalcanti. Depositou o Sr. Agamenon Magalhães. E saiu. Quem entrou a seguir foi o capitão Juracy Magalhães. Depositou o Sr. Marques dos Reis. E saiu.

Na sala de jantar, o Sr. Getúlio Vargas fazia sua oração fúnebre. Falava dos princípios da Revolução e da guerra que empreendera contra os corrilhos.

Não houve aplausos. Cada um recolheu seu chapéu, o general Góis Monteiro recolheu sua espada, o almirante Protogenes Guimarães assinalou tempo estável. Todos saíram por uma porta e o Sr. Vicente Ráo entrou pela outra, comandando a carga dos novos ministros.

Brevemente, terceiro jantar fúnebre. Cozinheiro: o do forte de Copacabana. ${ }^{21}$

A participação de São Paulo em dois ministérios intensificou, de forma significativa, a insatisfação do Correio da Manhã com o processo de alianças conduzido pelo governo constitucional. Os políticos paulistas penderam de vez para o lado do governo, sob a batuta de Armando de Salles Oliveira. A crítica à adesão paulista ao governo Vargas reverberou no artigo intitulado " $\mathrm{Da}$ ta Paulista” publicado, oportunamente, em julho de 1934, quando a Revolução paulista completava dois anos. Nele, Costa Rego combate, com vigor, as interpretações acerca do pretenso separatismo como motivo fundamental do 
movimento de 1932. Discutir a data paulista significava reaver seus sentidos e a lógica do movimento.

A interpretação do Correio da Manhã sobre essa questão permite reinscrever, na pauta, temas esquecidos ou por esquecer. Assim, o governo do estado de São Paulo permanece como alvo. A proximidade com o novo regime, comprovada na composição do ministério, alimentava a verve crítica do jornal contra um governo que parecia esquecer o significado de 1932. Armando de Salles Oliveira tornou-se presa fácil para o jornalista: o governador, ao se aproximar do ex-ditador em nome de uma possível união nacional, atingia metas discrepantes. Por um lado, ganhava influência nas decisões nacionais; por outro, abdicava do prestígio que o passado lhe conferia. O Correio da $\mathrm{Ma}$ $n h a ̃$ percebia a estratégia governamental que, mais uma vez, empenhava-se em conter e enquadrar a enorme força econômica e política de que São Paulo dispunha no desenvolvimento nacional. No debate acerca do movimento de 1932 já se deflagrava o embate sobre os usos do passado: a memória da Revolução de São Paulo represava, perigosamente, o sentimento de oposição a Vargas. As imagens da guerra poderiam acionar um conjunto de representações negativas do governo Vargas, afastando o principal estado brasileiro do projeto nacionalista defendido pelo presidente.

O restabelecimento do sistema representativo indicava que a negociação política era uma estratégia indispensável para qualquer governo, portanto, a oposição recuperaria seu poder no Parlamento. A formação de uma ativa minoria oposicionista já se anunciava no curto período em que a Constituinte se transformou em Câmara Ordinária, sob a liderança de Sampaio Correia. Confiava-se nas novas regras estabelecidas no pacto constitucional. A eleição do candidato que se fez "sucessor de si mesmo" criava uma continuidade ilusória entre o governo ditatorial e o constitucional. Não mais havia a figura do senhor ditador. Getúlio Vargas, constitucionalmente legitimado, teria de participar do complexo jogo de negociações que rege o Parlamento.

O retorno de Otávio Mangabeira, símbolo do pensamento liberal, da luta contra Vargas, e das demais lideranças do passado republicano, parecia assegurar o funcionamento das novas regras. O líder baiano era exemplo a ser admirado e seguido por sua persistência em conservar o passado liberal como herança capaz de iluminar o presente. Nessa ocasião, também Júlio Prestes retornou ao Brasil. Costa Rego propõe-se a devanear, elaborando uma alegoria do presente por meio de um fantasioso sonho do ex-presidente:

O primeiro andor era do nume tutelar, o eminente Sr. Getúlio Vargas, com inscrições patéticas sobre o dever dos governos de não indicarem candidatos a sucessão 
de si próprios. Vinte e dois interventores, não excluindo o de São Paulo, o carregavam, cantando os salmões penitenciais. Esse andor era lindo efeito, guarnecido de lírios, símbolo da pureza. Uma guarda de honra de cadetes o acompanhava. ${ }^{22}$

Os personagens da Revolução desfilam nesse ambiente alegórico. A última encenação supõe um movimento de massa.

A imensa passeata histórica era encerrada por uma alegoria ao 'Brasil Unido'. Um vasto caboclo, copiado dos que circundam a estátua de D. Pedro I (o imperador, não o paquete do Lloyd), mostrava aos povos um exemplar da mais linda lei eleitoral do mundo, onde há o voto secreto, destinado a evitar que os homens se perpetuem no poder. (ibidem, p.2)

Envoltas em ironia e humor, as cenas evocavam as distorções da Revolução. A esperança no governo constitucional, que se avivava com o retorno dos expatriados, parecia frágil, conforme se depreende do trecho final do artigo sobre Júlio Prestes:

Cruel decepção o aguarda.

Quando se entra na baía do Rio de Janeiro, pelo Norte, é um encanto apreciar, de longe, o conjunto das montanhas que formam o corpo de um gigante deitado - de um gigante que dorme, e possivelmente também sonha. Mire-o Sr. Júlio Prestes e observai que, ainda por longo tempo, a realidade da vida no Brasil, não vale a pena de acordar. (ibidem, p.2)

Chegamos ao fim de agosto de 1934, período limite para acompanharmos o nosso jornalista. Costa Rego encerrou a cobertura da Constituinte insistindo na construção de pontes entre o presente e o passado. A referência à estátua eqüestre do Imperador Pedro I atualizou o cenário. O monumento, motivo de grande polêmica na segunda metade do século XIX, servia então à nova representação do poder vigente: substituiu-se a Constituição pela lei eleitoral, trunfo do novo regime. Ambas, entretanto, a lei e a Constituição, resumiam-se a um mero despiste. Entre o sonho das antigas oligarquias depostas e o presente, ainda envolto em cores revolucionárias, havia riscos. Melhor não acordar. Júlio Prestes abandonou a política, enquanto Costa Rego parecia acreditar em suas apostas a despeito das inúmeras ameaças que espreitavam a ordem liberal.

Apesar da instabilidade política, a Constituição parecia indicar uma rota 
promissora para o Brasil. Mais uma vez o jornalista se detém na análise dos homens do passado, com especial atenção para Otávio Mangabeira. A memória exigia uma partilha de experiências que as novas gerações de políticos, advindos das hostes revolucionárias, pareciam desconhecer.

A insurreição de 1930, donde nasceu o governo provisório há pouco extinto, trouxe à tona muitos homens moços. Raros eram maiores de quarenta anos. Havia-os, às dúzias, menores de trinta. Isto, afinal, pouco teria importado se não acontecesse o que sucedeu: para um máximo de mocidade, surgiu um mínimo de experiência. Em inúmeros casos, a mocidade afogou a experiência. ${ }^{23}$

Entre expectativa e experiência anunciava-se claro desencontro. O sentido de orientação necessário à ação humana já não se encontrava nas vivências do passado. Os modelos oriundos da Europa, do período entre guerras, inspiravam a mocidade. Edmundo Bittencourt conservava as lições de ordem do positivismo castilhista, mas a ambição do Correio da Manhã extrapolava a fronteira do ofício de apenas informar a sociedade. $\mathrm{O}$ jornal se acostumara ao exercício do poder, em todos os sentidos. A nova ordem pretendia submeter a imprensa às regras inaceitáveis que restringiam a liberdade de expressão. Urgia resistir.

A imagem da Revolução de 1930, como um divisor de águas na política brasileira, era estranha aos contemporâneos da Primeira República, ainda atados àquela experiência política. Em torno do significado de ruptura, pretensamente provocada pelo movimento revolucionário, travou-se uma luta pela representação do passado. A princípio, era necessário demonstrar o contrário: os revolucionários traíram os ideais da Aliança Liberal, responsável pelo sucesso do movimento de 1930. O Correio da Manhã enfrentou as agruras do campo oposicionista com certa prudência: adaptou-se às novas regras da censura, mas soube aproveitar o debate na Constituinte de 1934 para se afirmar no poder e, portanto, como agente político que não poderia ser descartado. Costa Rego acertara no estilo curto e elegante de suas críticas. O experiente jornalista soube criar um modelo próprio de jornalismo, amparado no argumento racional fundado no método comparativo. Em setembro de 1934, assume a função de redator-chefe, passando a acompanhar, meticulosamente, todas as etapas da elaboração do jornal. O jornalista se acostumara a perseguir os acontecimentos políticos, sempre com atenção especial para Getúlio Vargas: 
De longa data me exerço na prática dos métodos mais sutis de adivinhação. Há cinco anos não faço senão isto: procuro pela manhã, descobrir o que estará pensando disto ou daquilo o fenomenal chefe do Estado que a Revolução, nos seus primeiros anos de ingenuidade, fez ditador e posteriormente, quando iniciada em todos os vícios, transmudou em presidente constitucional. ${ }^{24}$

A memória dos homens que organizaram a primeira experiência republicana começava a se desvanecer. A crítica de Costa Rego aos revolucionários consistia, entre outros pontos, na exigência de que a leitura dos acontecimentos fosse ordenada por um fluxo contínuo. O julgamento tanto do passado, quanto do presente, só seria justo nessa medida. Adotar perspectiva contrária seria farsa, impostura. De algum modo, a campanha do Correio da Manhã contra o governo provisório foi vitoriosa: a Constituinte poderia reconduzir o rio ao seu antigo leito. O 'sem-sentido' da Revolução de 1930 poderia ser domado e a ordem liberal se consolidaria, uma vez firmada a autoridade do governo constitucional. A eleição de Vargas representaria uma concessão necessária à reordenação política. A Constituição firmou um pacto confiável: cedeu às demandas centralizadoras, mas assegurou, no essencial, o pacto federativo.

Entre a sagração de 1930, como marco nacional, e o aprisionamento de 1932 à esfera regional, percebe-se que, rapidamente, a experiência política da Primeira República se fez longínqua. Esse distanciamento percorreu etapas: desde a guerra contra São Paulo até a promulgação de uma nova Constituição, parecia ainda existir um sentido de continuidade, alimentado pela permanência dos mesmos atores no cenário político. A ameaça comunista, em 1935, porém, restituiu a unidade entre as elites que abdicaram, momentaneamente, da defesa do ideário liberal em nome da ordem. O Estado Novo fundou uma nova representação do tempo, valorizando as tradições populares. Formulou-se, então, uma percepção do passado em que o folclore indicava uma tradição de longa duração a ser preservada, enquanto a história, assentada na trama dos acontecimentos, se deslocava para um passado distante, em busca dos processos definidores da nação. Os eventos recentes da experiência republicana pairavam, sem lugar, nas colagens que atualizavam o Estado Novo como síntese de um processo evolutivo, mas não encontraram destaque na produção intelectual dos historiadores. ${ }^{25}$

A reordenação do tempo histórico segue os fios de uma rede de interesses que escapam às antigas práticas republicanas. Os Estados, pequenas pátrias, perderam, então, a capacidade de dirigir a República. O golpe de 1937 fez-se em silêncio, apesar dos fartos indícios de sua ocorrência iminente. As vozes da imprensa e das oposições se acomodaram em um murmúrio conve- 
niente. Apenas o candidato Armando de Salles Oliveira encaminhou ao parlamento, em nome da defesa da democracia, um manifesto aos militares apressando, ao contrário do que pretendia, o golpe. A imprensa ajustou-se às novas regras e os representantes da ordem liberal seguiram o caminho do exílio.

Em 10 de novembro de 1937, Vargas pronunciou-se justificando o golpe. Em seu Manifesto à nação o presidente considera a Constituição de 1934 superada, "antedatada ao espírito do tempo". ${ }^{26}$ No mesmo dia, o presidente, sem fugir à sua rotina, compareceu a um jantar na embaixada Argentina. $\mathrm{O}$ feriado de 15 de novembro motivou a oportuna inauguração de um monumento em homenagem ao fundador da República, o general Deodoro da Fonseca. Havia uma memória a ser reverenciada e outra a ser negada ou reajustada. Enfim, os tempos eram outros. O Correio da Manhã teve que se adaptar à nova realidade, pois a instalação da ditadura contava com um sólido apoio dos militares e de quase todos os governadores. O jornalista Costa Rego aproveitou-se da inauguração do monumento para tecer uma crítica indireta ao governo Vargas:

O papel de Pedro II está na compreensão dos historiadores. O bronze perpetuou-lhe a memória, em Petrópolis; deveria perpetuar também a de Deodoro em seu monumento a inaugurar-se no Rio de Janeiro. Que este monumento não seja só o que é, pois deve ser muito mais: que ele seja, aos olhos de todos nós, um livro a ensinar-nos o que Deodoro fez de grande e o que aprendeu de pequeno - o que fez de grande proclamando - o que aprendeu de pequeno, governando a República. ${ }^{27}$

O exemplo de Deodoro é esclarecedor: a grandeza presente no gesto da proclamação da República opõe-se à pequenez do aprendizado do poder, pois para preservá-lo o general-presidente articulou um golpe, fechando o legislativo, cujo desdobramento motivou sua renúncia. Enfim, o jornalista apoiavase na história, como lição, para julgar os seus contemporâneos. Daí em diante, o novo tempo assumiria a tarefa de reordenação do passado, domesticando as formas de interpretação do presente e as expectativas de futuro. A experiência política que demarcou a moldura constitucional como projeto político nacional, em pouco mais de três anos, transformou-se num passado distante que se devia esconjurar e esquecer.

\section{NOTAS}

${ }^{1}$ Este trabalho é parte da pesquisa desenvolvida como atividade de pós-doutorado do Programa de Pós-Graduação em História do Centro de Pesquisa e Documentação da Funda- 
ção Getúlio Vargas (CPDOC/FGV), Entre a memória e a história: os exilados da velha república, sob a orientação da profa. dra. Ângela de Castro Gomes e com apoio do Conselho Nacional de Pesquisa (CNPq). Apresentam-se aqui os resultados parciais da análise dos artigos de Costa Rego sobre a Constituinte de 1934. O jornalista escrevia diariamente no jornal carioca Correio da Manhã, cujas edições compõem o acervo da Biblioteca Nacional.

${ }^{2}$ FRANCO, Afonso Arinos de Melo. Um estadista do império: Afrânio de Melo Franco e seu tempo. Rio de Janeiro: J. Olympio Ed., v.III, 1955, p.1369.

${ }^{3}$ SOBRINHO, Barbosa Lima. A verdade sobre a revolução de outubro - 1930. 3.ed. São Paulo: Alfa-Omega, 1983, p.171. Optei por uma concepção ampla de historiografia, privilegiando a relação da sociedade com seu passado. Nessa perspectiva, valoriza-se a diversidade de fontes que constituem, segundo Mássimo Mastrogregori, uma tradição de lembranças (MASTROGREGORI, Mássimo. Historiografia e tradição das lembranças. In: MALERBA, Jurandir [Org.]. A história escrita: teoria e história da historiografia. São Paulo: Contexto, 2006, p.65-93). Barbosa Lima Sobrinho, no prefácio à $1^{a}$ edição em 1933, reconhece a parcialidade dos escritos sobre 1930, mas identifica a necessidade da leitura de alguns testemunhos que reuniram farta documentação. Percebe-se, claramente, o desejo de legitimação da sua análise do presente que pretende ultrapassar o mero registro do acontecimento.

${ }^{4}$ Pedro da Costa Rego (1889-1954) nasceu em Alagoas. Órfão de pai e mãe, mudou-se para o Rio de Janeiro, ficando aos cuidados de seu tio, o jornalista Antônio José Oliveira e Silva. Em 1906 ingressou no Correio da Manhã, onde fez carreira. Ocupou posições de destaque na política alagoana como secretário de Estado (1912), Deputado Federal (19151917, 1918-1920, 1921-1923) e Governador (1924-1928). A revolução de 1930 interrompeu a sua carreira política no Senado (1929-1930). Estava na Europa presidindo a delegação brasileira na Conferência de Bruxelas, quando foi surpreendido pela revolução. Exilou-se em Cherburgo, na França, juntamente com João Mangabeira. Retornou ao Brasil no início de 1931. Elegeu-se Senador, também por Alagoas, em 1935. Em 1937, com a decretação do Estado Novo, perdeu o mandato. (SAPUCAIA, Antonio. O legendário Costa Rego. Maceió: Ed. Universidade de Alagoas, 2000).

${ }^{5}$ CANDIDO, Antonio. À guisa de introdução. A vida ao rés-do-chão. In: CANDIDO, A, [et. al.]. A crônica. Campinas (SP): Ed. Unicamp; Rio de Janeiro: Fundação Casa de Rui Barbosa, 1992. p.13-22.

${ }^{6}$ MEDEIROS E ALBUQUERQUE. Quando eu era vivo. Memórias (1867-1934). Porto Alegre: Globo, 1942, p.196.

${ }^{7}$ REGO, Pedro da Costa. O novo e o velho. Correio da Manhãa, p.2, 2 maio 1931.

${ }^{8}$ REGO, Pedro da Costa. Ver, ouvir e dizer. Correio da Manhã, p.2, 1 nov. 1933.

${ }^{9}$ REGO, Pedro da Costa. Barbas para um. Correio da Manhã, p.2, 1 dez. 1933. Grifo nosso.

${ }^{10}$ REGO, Pedro da Costa. As dezesseis facadas. Correio da Manhã, p.2, 4 jan. 1934. 
${ }^{11}$ REGO, Pedro da Costa. Drama evidente. Correio da Manhã, p.2, 6 jan. 1934.

${ }^{12}$ REGO, Pedro da Costa. A Pesca do pirarucu. Correio da Manhã, p.2, 12 jan. 1934. O termo 'pirarucu' se popularizou como sinônimo de tombo ou golpe político.

${ }^{13}$ FRANCO, Afonso Arinos de Melo. A alma do tempo. Memórias. Brasília: Instituto Nacional do Livro; Rio de Janeiro: J. Olympio Ed., 1979, p.312.

${ }^{14}$ REGO, Pedro da Costa. O anistiado. Correio da Manhã, p.2, 31 mai. 1934.

${ }^{15}$ REGO, Pedro da Costa. A verdadeira desgraça. Correio da Manhã, p.2, 1 jun. 1934.

${ }^{16}$ REGO, Pedro da Costa. O que menos importa. Correio da Manhã, p.2, 2 jun. 1934.

${ }^{17}$ REGO, Pedro da Costa. Os candidatos. Correio da Manhã, p.2, 26 jun. 1934.

${ }^{18}$ REGO, Pedro da Costa. Usurpação. Correio da Manhã, p.2, 17 jun. 1934.

${ }^{19}$ REGO, Pedro da Costa. Freio e contra-peso. Correio da Manhã, p.2, 21 jul. 1934.

${ }^{20}$ O Sr. Getúlio Vargas dirigiu, ontem, um manifesto a nação. Correio da Manhã, p.2, 21 jul. 1934.

${ }^{21}$ REGO, Pedro da Costa. O jantar fúnebre. Correio da Manhã, p.2, 1 ago. 1934.

${ }^{22}$ REGO, Pedro da Costa A pena de acordar. Correio da Manhã, p.2, 18 ago. 1934.

${ }^{23}$ REGO, Pedro da Costa. O homem e sua atitude. Correio da Manhã, p.2, 24 ago. 1934.

${ }^{24}$ REGO, Pedro da Costa. Idéia de um outro autor. Correio da Manhã, p.2, 2 nov. 1935.

${ }^{25}$ GOMES, Ângela de Castro. História e historiadores. Rio de Janeiro: Ed. FGV, 1996.

${ }^{26}$ VARGAS, Getúlio. A nova política do Brasil. Rio de Janeiro: J. Olympio Ed., v.V, 1950, p.19-32.

${ }^{27}$ REGO, Pedro da Costa. O monumento a Deodoro. Correio da Manhã, p.2, 10 nov. 1937.

Artigo recebido em fevereiro de 2008. Aprovado em abril de 2008. 